\title{
Local Election Competition for National Party Survival: An Analysis of Merlimau By-Election in Malaysia
}

\author{
Moniruzzaman M. (Corresponding author) \\ Associate Professor, Department of Political Science \\ International Islamic University Malaysia \\ Jalan Gombak, Kuala Lumpur 53100 Malaysia \\ Tel: 03-6196-6056E-mail: mmzaman@iium.edu.my
}

Received: February 3, 2016 Accepted: March 22, 2016 Published: March 23, 2016

doi: $10.5296 /$ jsss.v3i2.9202

URL: http://dx.doi.org/10.5296/jsss.v3i2.9202

\begin{abstract}
Party politics in Malaysia has become tumultuous over the past two decades. As such national and regional level elections as well as by-elections have become equally sensitive for party politics. Of late by-elections have taken a special position as they are considered unseasonal barometer for testing popularity and legitimacy of the incumbent and the opposition competition. The effect of the dramatic 2008 national general elections in Malaysia continued during the subsequent three years through nearly one and a half dozen by-elections throughout the country. Until November 2010, the opposition remained jubilant over its victory in eight out of 11 by-elections maintaining the funfair of the rising opposition unprecedented in Malaysia's election history. But the tide started to dwindle with the subsequent three wins in Galas, Tenang and Batu Sapi by the ruling coalition turning the trend around. Under this circumstance came the Merlimau by-election in March 2011. Reflecting the reality on the ground, therefore, this by-election became a battleground for party political survival for both the ruling and opposition coalitions. This article discusses the campaign strategies of the competing coalitions, the results of the election, and its implications. The importance of this by-election is that it reflected the intensity of national level electoral sensitivity since the ruling party's political survival was dependent upon wining this election against a series of by-elections won by the opposition.
\end{abstract}

Keywords: Malaysia, Malaysian Politics, Party Politics, By-elections, Merlimau by-election 


\section{Introduction}

Party politics in Malaysia has become tumultuous over the past two decades which is reflective in fierce party competition, emergence of new parties, coalition formation, and alliance-based election competition. As such national and regional level elections as well as by-elections have become equally sensitive for party politics. Of late by-elections have taken a special position as they are considered unseasonal barometer for testing popularity and legitimacy of the incumbent and the opposition competition. The sound and beat of the dramatic 2008 national general elections in Malaysia continued during the subsequent three years through nearly one and a half dozen by-elections. Through these by-elections the electoral constituencies still felt after-shocks and strong tremors of the election earthquake that rattled the political landscape in 2008. Until November 2010 the opposition remained jubilant over its victory in eight out of 11 by-elections maintaining the funfair of the rising opposition unprecedented in Malaysia's election history. Since the general election held in March 2008, all the states in Malaysia, except Perlis, have had at least one by-election each. The remaining two states, Pahang and Melaka, were to conduct one each simultaneously on March 6, 2011. So the heat of the funfair was felt all over the country. But the tide started to dwindle with the subsequent three wins in Galas, Tenang and Batu Sapi by the ruling coalition turning the trend around. Under this circumstance came the Merlimau by-election in March 2011. Reflecting the reality on the ground, therefore, this by-election became a battleground for party political survival for both the ruling and opposition coalitions.

This article will discuss the strategies the competing coalitions of parties have employed in the election to win the voters, the results of the election, and its implications. The importance of this by-election is that it reflected the intensity of national level electoral sensitivity since the ruling party's political survival was dependent upon wining this election against a series of by-election win by the opposition. The data for this article was sourced primarily from the local dailies and other electronic media. And the analysis presented in the article is descriptive-comparative.

\section{The Electoral and Party Systems in Malaysia}

Malaysia, a constitutional monarchy, has a political system of parliamentary democracy. It is composed of 13 states and three Federal Territories. The Peoples Assembly (Dewan Rakyat) of its bicameral legislature has 222 seats, and the National Assembly (Dewan Negara) has 70 seats. The representatives at the Peoples Assembly are directly elected for a five-year term, and the National Assembly members are elected by state assemblies and some are appointed by the King. Like Peoples Assembly, the 13 states have directly elected local assemblies for a five-year term. Both national and state assembly elections are held simultaneously except in the state of Sarawak. Starting in 1959, following independence in 1957, Malaysia has conducted 13 general elections, the last being in 2013. Since independence, the government has been controlled by the UMNO (United Malays National Organisation) dominated Barisan Nasional (BN), the ruling coalition. As in any parliamentary democracy, the country has experienced numerous by-elections both for national and local level assemblies.

Malaysia has been maintaining a multiparty system. The Election Commission (EC) registry lists 33 political parties, 13 of which are partners to the ruling coalition Barisan Nasional $(\mathrm{BN})$. The party system of Malaysia has experienced a unique one-party dominant rule for the 
first few decades. However, after 1998 political instability followed by the sacking of Deputy Prime Minister Anwar Ibrahim from power, the country has moved to a bi-coalition system (Moten, 2009). The first serious challenge the ruling BN faced was in 2004 national as well as regional elections when the opposition led by Parti KeAdilan Rakyat (PKR) emerged as a strong alternative (Pandian, 2009). During the following elections in 2008 and 2013 the opposition took a concrete coalition shape under the name Pakatan Rakyat (PR) composed of three mainstream parties - PKR, Parti seIslam Malaysia (PAS) and Democratic Action Party (DAP). The opposition coalition has since 2004 vigorously contested in regular as well as all by-elections.

\section{Literature Review}

Studies on Malaysian elections are prolific. Malaysia is one of the few developing countries that has maintained election regularity and elected government for about six decades. Yet its election practice is highly criticized both locally and internationally by academics and public media (Case, 2011; Puthucheary \& Norani, 2005; Pepinsky, 2007). There are a number of issues that are considered to be the major characteristics of Malaysian elections. Firstly, due to its uninterrupted one-party rule the ruling party has always maintained its hegemonic presence during any election until 1990s. The opposition parties have barely survived in politics at the national level. However, some opposition have fared well in state level elections so much that they took control of a number of state assemblies and governments since early 1990s. This trend became more obvious since 2008 elections when more state assemblies and governments went to opposition coalition (Moten, 2008). Since then the electoral politics turned real competitive (Weiss, 2013; Welsh, 2013; Moniruzzaman, 2013).

Secondly, monetary corruption is thought to be widespread in electoral competition in general since long. The ruling coalition takes advantage of the public money and resources in garnering people's support through allocation of fund and projects immediately before elections. Furthermore, vote-buying using cash during election campaign or on the polling day is a common allegation (Pepinsky, 2007). Thirdly, being a multi-ethnic country, the Malay, Chinese and Indian communities maintain ethnic-based political parties which make elections racially charged. Even though the ruling coalition combines the mainstream racial parties, internal rivalries as well as opposition parties of the same race come face to face during elections (Prasad, 2015). Fourth, since the entire politics is largely considered to be patrimonial and clientelistic in nature, election politics is marred with informal favoritism between political parties and the electorate (Johansson, 2014; Pepinsky, 2007).

Fifth, until the appearance of modern social media election campaign almost absolutely used to be under the control of the ruling coalition due to the fact that the coalition partner parties own the major print and electronic media. Until 1990s the opposition campaign remained fairly invisible in public media. But this scenario has been changed since 2004 elections (Khalid \& Halimah, 2008). At present the ruling and the opposition make equal use of the social media in particular to wage their electoral war against each other. And finally, moral scandal and financial corruption have become overwhelming issues during election battles. The ruling coalition is alleged to have deliberately used the judiciary and the police to curb the prominent opposition figures in an attempt to win over the elections (Case, 2014; Saravanamuttu et al., 2015). 


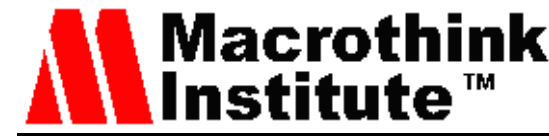

The existing literatures on Malaysia's by-election politics display similar characteristics. However, compared to the corpus of literature on national level elections, its number on by-elections are few. A recent study entitled Democracy at Stake?: Examining 16 by-elections in Malaysia 2008-2011 (Huat \& Soon, 2012) is an extensive undertaking to record the trend in the recent past. This study has confirmed that by-elections in Malaysia are no less than the election festivity during general elections. Especially after 2004, by-elections have become even acid test for political parties because they could have serious consequences at the national level. The point that is important is that since the opposition is much stronger, both ruling and the opposition tend to take by-elections more seriously in the recent time (Ishak \& Fong, 2013; Hamzah et al., 2014; Nakamura, 2013). So like many recent by-elections, Merlimau by-election experienced similar intense competition between the rival coalitions.

\section{Merlimau By-Election Announced}

Merlimau is a State Assembly constituency situated in the state of Melaka (Malacca). The Federal Constitutional law requires a by-election to be held to fill a seat that falls vacant within the first three years of the five-year term parliament or State Assembly. Upon the death of the assemblyman Mohammad Hidir Abu Hassan on January 20, 2011, the Election Commission on January 28 announced the seat vacant. At the same time, the Commission made the announcement of by-election in Merlimau to be held on March 6 for which nomination day was set for February 26. So the announcement of the election came even before the polling day of the Tenang state by-election to be held on January 30 keeping the election momentum ever high.

\subsection{The Constituency of Merlimau}

Merlimau is a constituency in the state of Melaka which is located on the south-west coast of Peninsular Malaysia. On October 20, 2010 the Prime Minister of Malaysia Najib Tun Razak declared the state of Melaka as a "developed state" according to the 32 criteria set by the Organisation of Economic Cooperation and Development (OECD) to qualify as a developed economy. This was reportedly achieved by a 10-year plan called Melaka Maju 2010 that improved the GNP per capita in Melaka to US $\$ 14,261$ by leveling the poverty rate to 0.5 per cent from 5.4 percent in 2000. As such the Merlimau constituency is one of the most prosperous and developed areas in Malaysia. Yet being located away from the historic port-city of Melaka, the state capital, Merlimau is still considered a semi-urban constituency.

As a multiethnic country, Merlimau is reflective of its ethnic mosaic. Merlimau is a mixed seat with 65 per cent of the voters being Malays, and 35 per cent being Chinese and Indians. Of the total 10,679 voters, the Malays account for 6,895 (69.15\%), the Chinese accounted for 2,228 (20.85\%) and Indians for 1,576 (14.67), and 37 of other races. Among the voters 5,087 are men and 5,592 are women (John, 2011). From the perspective of elections, Merlimau has always remained a Barison Nasional (BN) stronghold since 1955, the first general elections in Malaysia. Due to changes in the national political trend, Merlimau experienced declining BN support in the recent past elections. While in 2004 general elections, the BN retained its majority by 5,087 votes, it lost its ground substantially in 2008 elections, winning by just 2,154 votes. In terms of electoral districts, Merlimau has seven voting areas including two in the main city center. 


\subsection{Politics of Nomination}

The recent by-election politics became increasingly precarious due to successive loss for the opposition and corresponding win for the ruling coalition. This put the competing camps at a loggerhead intensified by the facts that a parallel contest was to be faced by them on the same March 6 polling day in another constituency, Kerdau (Pahang), while they were on the fighting ground in Tenang (Johor) on January 30. The nomination of candidates therefore became a serious concern in this by-election.

Speculations over candidacy, nomination and contesting the election started to surface just two days following the death of the incumbent member. The BN was obviously upfront in this due to its popularity in the state as well as in the constituency (Melaka BN.., 2011). On 22 January, the Melaka Chief Minister who was also the Melaka BN Chairman indicated in a public occasion of the party's intention and confidence in fielding a suitable candidate and contesting the election (BN to field.., 2011a). The obvious opposition, the Pakatan on the other hand remained undecided for about two weeks before and after the seat was officially declared vacant and up for contest.

Despite the parties being busy with the ongoing election campaign in Tenang, they were preparing for the upcoming contest as well. The BN was found to be most ready to keep the field under its control. A day after the EC announced the nomination and by-election date, the BN on January 29 appointed by-election director to be headed by the Melaka state Chief Minister Mohd Ali Rustam who was the chairman of the Melaka BN as well. However, for both the ruling and opposition camps fielding an appropriate candidate was a risky business. The parties had to calculate the loss and gain in the previous elections and decide accordingly for better election results. Apparently the $\mathrm{BN}$ had at least seven candidates in the lineup which was indicative of its strong position, but simultaneously it created the problem of selection. Tradition in the party in practice was that candidates were selected from the party rank and file suggested by the state level party chairman and approved by the central leadership. But following the disastrous election results in 2008 and in the follow up by-elections, the $\mathrm{BN}$ explicitly changed the practice. The change was motivated by the loss in the past to regain the party's position and at the same time inspired by the gains in the immediate past by-elections to continue its momentum. Dictated by both needs the Prime Minister Najib Tun Razak, the party chairman, had reportedly reset the criteria for choosing the candidate based on the popularity of candidates among the people not in the party. Reflecting this policy the election director announced that "[A] candidate who is popular among the masses can win. If one is popular in the party but unpopular outside the party, it will be difficult to get the votes. There is no problem (on the candidate), we will choose the best, who can win, who is supported and liked by the people" (BN to field.., 2011). The Jasin Umno division, Merlimau being part thereof, had suggested seven candidates of which the Director intended to seek approval from top three by the party chairman. Finally, Barisan's Roslan Ahmed was chosen to contest the seat on party's behalf.

The opposition politics in Merlimau remained active all along but weak in performance. The most viable and closest contestant was PAS as it contested here in 1999 and 2008 elections, while it was PKR that contested in 2004. Due to the shaky position of the opposition bloc composed of PKR-DAP-PAS, choosing of a candidate to face the BN man was a serious 
issue of concern. Apparently, the bloc was unsure whether to field a candidate with the grand Pakatan label or with component party label. The PAS youth front from the very beginning demanded for the "party's right to contest based on a said pact that the status quo on the allotted seats should be maintained until the next general election" (PAS youth.., 2011). On the other hand, the PKR youth chief insisted that even "though PAS deserved to contest the seat according to the status quo, the prevailing circumstances favoured a PKR candidate" (Opposition to meet.., 2011). As such the opposition alliance experienced an internal rift on the candidate issue till the last week of January. The competing right to contest forced the alliance to go for a joint decision making process on candidate selection which made the claimants temporarily down tone their respective claim. At one point the PAS even conceded to the extent of letting allies contest the election. After a week of negotiation following its recent defeat on January 31 in Tenang, by early second week of February it became clear that a PAS candidate would be nominated for the contest. Out of reportedly several shortlisted prospective candidates including a woman, Yuhaizad Abdullah was finally selected to contest the election.

\section{Campaign Strategies and Issues: Ceramah and Charms}

\subsection{The BN Strategy}

\subsubsection{Capitalizing Popularity of the Chief Minister}

One of the strategies that the $\mathrm{BN}$ has used is capitalizing the popularity of the state Chief Minister himself Mohd Ali Rustam. Immensely popular in his state as well as in the party, Ali Rustam was put upfront in the election festivity. Known as “Mr. Likeable" Ali Rustam's challenge in the contest was multidimensional- as the state Chief, state BN chief and as the election director. As such he took the contest as a personal mission and had campaigned vigorously as though he was the candidate himself. As one political commentator observed "Everywhere one turns, there he is, smiling and waving back- from a banner, poster or some giant billboard" (Tan, 2011a). Indeed, Ali Rustam had started his election campaign tour a week before the nomination and election dates were announced. Even before announcing the candidate he commented saying that "I have begun visiting the community in Merlimau to find out their needs, and four weeks before nomination day, we will multiply our machinery's efforts and energy" (Melaka BN ready.., 2011).

\subsubsection{Capitalizing Popularity of the Candidate}

As mentioned earlier that the choosing of candidate this time depended on local popularity and acceptability of the candidate rather than party rank and file. Besides having the advantage of Merlimau being an UMNO fortress since 1955, BN rather prioritized winning the race by fielding a candidate that can make the race all the more comfortable. The party chose a youthful Roslan, only 44, who had three clear advantages. Firstly, family political inheritance was strong for his candidacy background. He is a son and nephew of two former local and state leaders which makes his political credibility weigh heavier in the eyes of the voters. Secondly, locality of the candidate was given a serious consideration in choosing the candidate. Roslan was from Merlimau Pasir, which is adjacent to the Merlimau town. And finally, easy accessibility of the voters to the candidate and vice versa. The deceased assemblyman Mohd Hidir was known among the voters as "a people-person and very 
hardworking," and so they expected the next leader emulating his people-centered characters (Elis, 2011).

\subsubsection{Capitalizing on Economic Performance}

The biggest advantage $\mathrm{BN}$ had in the election was its economic development delivery to the people of Melaka giving them the status of a developed state just three months earlier. This achievement was a political boost for the party and for the people as well. It increased their image, prestige and pride that the state has achieved the targeted level of prosperity well ahead of Vision 2020. The feeling of this achievement just three months ago was still very much fresh in the minds of the voters, and the BN could legitimately bank on the feeling of the people to claim the credit for keeping the political promises and bringing development to the peoples' door (Heng, 2011). The ruling party always enjoys advantage over the opposition due to the state fund availability or purposefully reallocating funds with special effects. Although a mere coincidental, the completion of a small retail market renovation and transformation on February 15 under the government's RM 60 million Small Retailer Transformation Program (Tukar) has been clearly capitalized by the BN campaign camp. The BN high officials paid multiple visits to the Pasar Mini Baru Merlimau before and during the campaign period. During such visits the beneficiaries' pleasure and satisfaction were registered in the media as success of the BN development strategy for Vision 2020. To add to its credits the Domestic Trade, Cooperatives and Consumerism minister in one visit to the Pasar Mini announced another RM 60 million to implement the Tukar program (Tuker improves...2011). Even though the project is under the federal government, a completion of such project in Merlimau during election time was a clear campaign advantage for the BN. Furthermore, just 4 days before the polling, the Melaka government announced to complete an abandoned Islamic Council complex, despite objection by PAS, using the Zakat fund (Malacca aims.., 2011).

\subsubsection{Capitalizing on Election Cookies}

Election cookies are common in Malaysia. These usually come in the form of government announcement of new projects immediately before the election, and undertaking projects and giving out welfare goodies during the campaign period.

Other than the big state projects, the party and its components organized cheramahs and dinners during the campaign period (Yee, 2011a). The Umno Youth held a ceramah attracting about 150 people all of whom were reportedly supplied with Umno blue shirts. A pro-BN businessmen group had thrown a series of 1Malaysia dinners with free 1Malaysia T-shirts at SJKC Merlimau for the Malay, Indians and Chinese communities just few days before the poll. Despite the claim that the dinners were non-political these were obviously so as these became talk of the town. The election cookies were 'non-politically' distributed in the dinners in the form on lucky draw. Even though these were called lucky draws followed by free dinners, the organizers made sure that every participant was lucky enough to take home at least one of the many items such as motorcycles, bicycles, electrical home appliances and other gift hampers.

\subsubsection{Capitalizing on Opposition Weakness}




\section{MInstitute ${ }^{\text {Mink }}$}

Coupled with the delivery of economic goods to the people on the one hand, it was the weakness of the opposition alliance, on the other, that BN had capitalized much. Over the past two years a number of issues and scandals had rocked the opposition alliance to their disgraceful embarrassment. The de facto leader of the Parti KaAdilan Anwar Ibrahim's image had been much tainted by the recent allegation of sexual misconduct on which he was fighting a court battle. A number of times earlier PAS and DAP came confronting each other on respective party stand on sensitive political and ideological issues. Having based on Islamic ideology PAS at one time declared its intention to establish the Islamic Shariah laws in Malaysia if it can form the government at the federal level. This was strongly and instantly criticized by the DAP, a secular Chinese based party. This contradicting party stands made the shaky and marriage of convenience-coalition apparent to the people. And more recently, just a few days before Merlimau polling day, the PAS led government in the state of Kelantan prohibited the sale of Big Sweep lottery tickets on it being an act of gambling which is against the Islamic Shariah. At the same time, the government imposed prohibition on celebrating the upcoming Valentine's Day as against the Islamic spirit. DAP publicly criticized this decision of PAS in Kelantan (DAP blames, 2011).

The BN in its campaign successfully highlighted the weaknesses of the opposition camp on a number of grounds. Firstly, it pointed out to the voters that the opposition alliance was indeed a fragile pact without a common policy framework and political objectives. The parties were ideologically so heterogeneous that it would be impossible for them to produce a common good for the people. Secondly, the BN campaign pointed out that the opposition alliance suffered from internal differences, non-cooperation and non-coordination manifested in policy making where the partners were not consulted (Gasper, 2011). And finally, the alliance's top leader's credibility over his alleged sexual misconduct offered the BN a moral superiority in the race. To make the campaign a bit more spicy over the issue, it is alleged that the $\mathrm{BN}$ or some perpetrators with its support had come up with some explicit doctored pamphlets just a few days after the nomination featuring a number of opposition concerned figures such as Anwar Ibrahim, his sodomy accuser Saiful Bukhary Azlan, Selangor exco member Elizabeth Wong and the self-styled flamboyant Ummi Hafilda (Tan, 2011b). Such pamphlets helped the BN to build a negative public opinion against the opposition alliance and in favour of the $\mathrm{BN}$.

\subsubsection{Capitalizing on Political Momentum}

By the time the unofficial campaign period started the BN had already bagged in another win in Tenang by-election on 31 January. This was the third successive win for the ruling $\mathrm{BN}$ which was a major boost for its political morale. The jubilant BN already was enjoying a psychological advantage over the rival opposition considering the trend as a momentum. Using modern communication technology of both print and electronic media the BN campaign highlighted the Tenang win as morale booster for the voters.

\subsubsection{Mobilization of the Coalition Machinery}

The BN coalition machinery was naturally more energetic with the momentum aided by the Tenang win, and scandalous and internally conflicting opposition weakness. The BN employed its full machinery composed of elements such as the UMNO, MCA, MIC, UMNO Wanita and Youth. 


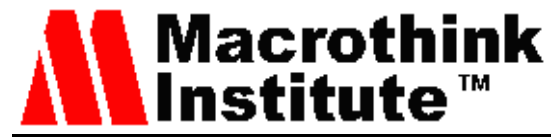

The Umno stake in the election was higher in Merlimau than anywhere else. Above all the contest involved the good image of the leader Ali Rustam as the state chief and party division chief. Secondly, wining with higher majority than the previous election was an explicit stated objective. And thirdly, simultaneous polling in the state of the Prime Minister itself was a tremendous pressure for performance for Umno. As such all its machinery including Wanita and Youth wings were employed to the full. Despite the known fact that PAS was weak in the constituency, the Umno sweeping campaign strategy consciously avoided any risk taking.

The MIC in its campaign bid steered its machinery under its president at the party operation center in Merlimau. With a good strength of 120 supporters he initiated the campaign to work round the clock to get more Indian votes in the area. Reflecting on the political rift in the Indian community in the recent past, the president emphasized on showing their 'strength in a united manner.' During the 2008 elections, the Indians voters massively swung to the new Indian party Makkal Sakti that was a part of the opposition alliance. Now with the subsiding of the internal conflict, the MIC in Merlimau set to garner over 90 per cent of the Indian voters for the BN.

Especially interesting was the demand of the UMNO Wanita wing to field a female candidate Umno Wanita division chief Zahela Bujang. The central Umno Wanita chief has reportedly played the female card in response to the PAS fielding of a female candidate in the Tenang election. Claiming 'experience, skill and good leadership' her demand for a female candidate was expressive of the Wing's preparedness to back up the BN campaign.

\subsection{The Opposition Campaign Strategy}

The opposition was clearly in a weaker position after the loss in Tenang by-election just little more than two months ago. The political wind was blowing against its favour. Yet it tried to maintain a vigorous campaign aiming at saving its position from going further downhill. However, as usual the opposition had little at hand to make an impressive appearance collectively.

\subsubsection{Capitalizing on Corruption}

The opposition was under heavy pressure to face the identity question of 'Male $\mathrm{Y}$ ' whose DNA was reportedly found on the person of Saiful Bukhary Azlan, the accuser of sexual misconduct against the opposition leader Anwar Ibrahim. Yet the opposition tried to capitalize on the general accusation of corruption against the BN leaders and the government. Issues such as Apco and the use of Zakat fund were taken up to label the government with corruption (Malacca aims to.., 2011).

\subsubsection{Capitalizing on Development lag-behind}

The opposition was critical of the development status of the state that the government had recently claimed. It apparently did not completely agree to the government claim. Therefore, instead of rejecting the numeric achievement of the state-wide claimed development status, the opposition tried to localize the issue by indicating under-development in the locality of Merlimau. It questioned the per capita income claim by the state government as false on the ground that the income level achievement stood only to mean the average, not the actual. Furthermore, the opposition claimed that the income inequality between the urban and Merlimau rural people was significant to mean that the government had failed to equally 
distribute development benefits in all regions. The PAS election commissioner remarked "in Melaka, for example, we are declared as a developed state, but how about the people? Are the Melaka people rich? Those who are rich only the elites in UMNO and BN, but many people including members and supporters of UMNO and BN are not as rich as before" (Melaka PAS says.., 2011). A particular issue was taken up by the opposition is the absence of a supermarket in Merlimau for the local people. Though the BN claimed that the supermarket was a non-issue since many such markets were available in the Melaka city, which is not very far away from Merlimau, the opposition apparently had a point to make it a legitimate case before the voters.

\subsubsection{Ceramah Fight}

The opposition had used the system of Cheramah (community campaign) likewise the ruling party. All the three components of the alliance had their cheramah organized by their respective wanita (women) and youth wings. Many of these ceramahs were attended by the de facto leader Anwar Ibrahim attracting the biggest crowds among the alliance. Similarly the PAS deputy president had also attended ceramahs but failed to gain impressive attendance. Since Merlimau is considered an Umno stronghold the battle for PAS and KeAdilan to get the Malay voters was not easy. However, it was the Chinese voters that made the MCA and DAP fight head on. Especially the youth wings of both MCA and DAP held a festive confrontation of each other in the local China Town (Yee, 2011b). Both parties throttled each other politically on issues such as the "love-affair" between PAS and DAP, Islamic state. In these ceramahs it is reported that the MCA machinery had overpowered the DAP by the presence of high ranking political figures such as the Deputy Education Minister who was a Chinese, high volume karaoke event and the Chinese pop idol of Merlimau contest. The DAP ceramah also could not match the MCA's sway over Chinese associations, temples and schools in Merlimau that put the opposition in a weaker position (Tan, 2011c).

In a ceramah meeting the DAP accused the BN of creating a fear factor among the Chinese voters by propagating that it would know the people who did not vote for the BN. The Dap also rebuked the MCA allegation about the Islamic state issue, but its failure to take up the challenge thrown by a Chinese NGO to a debate on the same issue weakened its position further. As such it is observed that DAP even failed to promote Yuhaizad the way it did for the Tenang candidate (Yee, 2011c).

\subsubsection{Candidate Image}

After much negotiation a PAS candidate was chosen to contest. Like BN, PAS also emphasized on the candidate's local popularity. Initial speculation was that PAS may field a female candidate again in Merlimau like in Tenang, but it had several other candidates shortlisted. The PAS election commissioner said "we have decided to choose a local person as candidate in order to avoid issued such as the acceptance of the voters towards the candidate" (Melaka PAS says...2011). Interestingly, the PAS election poster incorporated the DAP party colour with red background ('ong' in Chinese for lucky colour for the Chinese) instead of green. However, it appeared that the opposition candidate could not create an impressive image among the voters as he came from a village 20 kilometers away from the Merlimau town, compared to his rival who was just from the nearby of the town. 


\subsubsection{Criticizing Government Machineries and Election Cookies}

The opposition took an offensive stand against the BN campaign calling it 'dirty tactics.' Reportedly the dirty tactics referred to the 'sexy' doctored posters depicting several Pakatan leaders in sexually-explicit poses (Yee et al. 2011). However, both camps denied the allegation behind the production and distribution of the posters and held the opponent responsible for it. Similarly, the opposition accused the BN of using the government machineries and election cookies as 'political candy' such as dinners and gifts to lure the voters. But it could not withstand the counter-argument that "efforts to help the needy during elections must not be politicized... do we have to stop giving out aid although we know there are people in election areas who need help, just because others may say it is "election candy?" (Heng: Don't.., 2011). However, the fact remains that such seasonal distributions of 'election candy' does bear political consequences, so foul cried the opposition.

\section{Election Results and Analysis}

According to the Election Commission gazette (Table 1), the BN candidate gained 5,962 and the PAS candidate Yuhaizad received 2,319 votes of the total 8,416 votes cast. There was an impressive 79 per cent voter turnout. The result gave the BN candidate a 3,643 votes majority which was much higher than the targeted 3,500, and much higher compared with its 2,154 majority in 2008 elections. The result was a very comfortable win for the BN.

Though it was perceived earlier by many that the election result was foregone for $\mathrm{BN}$, a number of implications are in point. Firstly, strong and continuous reinforcement of the BN presence in Merlimau which is substantiated by the fact that it won in all seven voting areas including the two in the main town. Certainly, the traditional post-1955 legacy was continued probably influenced by the mind-set, but nevertheless must have been influenced by government's economic and social welfare delivery. Merlimau was thought to be different from some other particular areas where the government's FELDA scheme sometimes made them fortified voting blocs. In contrast, Merlimau people enjoy freedom from such economic and political clientilism to make their mind during elections. That the voters with a higher majority have chosen to continue their support for the $\mathrm{BN}$ is a testimony of their satisfaction with the government performance (Tan, 2011d). 
Table 1. Results of Merlimau By-election, 2011

\begin{tabular}{lll}
\hline Total Votes & & 10,679 \\
\hline Candidates, Party and votes & & \\
Roslan Bin Ahmad & BN & 5,962 \\
Yuhaizad Bin Abdullah & PAS & 2,319 \\
Total votes received & & 8,281 \\
Voters Turnout & & $79 \%$ \\
Winning Majority (BN) & & 3,643 \\
\hline
\end{tabular}

Source: Election Commission Malaysia.

http://www.spr.gov.my/eng/index_files/result_prayaVBI/N27MERLIMAU.pdf

Secondly, the fourth straight win in a row had its implication at the national level. The Prime Minister immediately after the announcement of the result commented the win as "very significant.' Indeed, the significance can be considered multidimensional. Above all, a fourth straight win helped put the $\mathrm{BN}$ in its normal national leading role which was seriously under challenge since its relatively poor performance in 2008 elections. The party was desperate to place it back on track. Then comes the popularity and leadership question of the Prime Minister himself. The election wins consolidate the leadership's capability and popularity and strengthen his confidence in the next general elections. And finally, the 'very significant' win is considered by the party and the government as public endorsement of the government's policies. The Deputy Prime Minister at the time Mohyuddin Yasin claimed that "Barisan's impressive victories were an endorsement of the economic and social programs initiated by the government under Najib's leadership" (Najib vows to.., 2011). Similar claims were separately made by the MCA and MIC leaderships saying that the voters were returning to the ruling coalition with higher significance (Najib vows t.., 2011). Furthermore, the BN alliance claimed that the win is indicative of advancement of popular support for 1Malaysia concept that the Prime Minister has introduced recently.

Thirdly, if the win is considered very significant for the ruling coalition, then the loss is equally very significant for the opposition as well. The fourth straight loss has only pushed the opposition's political slide further down. Internal unstable relations between the partners and their de facto leadership's moral controversy is further destabilized and complicated by the loss. These are reflected in the retrospective claims made by the ruling coalition. The coalition claims that its win is also reflective of the rejection of the opposition and PAS in particular. In the DPM's words "this is an indication that the party's struggles are not accepted by the Malays...it is a signal that that PAS has been rejected not only by the Malays but also by other races who showed their protest at today's polls" (Najib vows to.., 2011). Making remark particularly to the DAP, the MCA president observed that "the Chinese no longer succumbed to DAP's irresponsible ways of politicking- slogan-shouting and making empty promises" (Najib vows t.., 2011). Observers believe that there are several reasons why especially the Malays have been turning their back to PAS and returning to Umno (AbuBakar, 2011). Firstly, lack of trust of the Malays in PAS about their economic and political future that the party is not capable of delivering nationally what it can promise. Its ideological 
rhetoric is sweeter than its pragmatic capability. Secondly, the party is unsure about its dilemma on safeguarding the Malay interest first and maintaining its secular DAP partner happy to keep the alliance going. The obvious rift between the two on Islamic issues is well registered by the people. Thirdly, PAS's new liberal and accommodative politics of non-Muslim membership is an awkward shift of its ideology for the rural conservative Malays who might feel it as a significant deviation. Finally, apparently Anwar Ibrahim has become a liability for PAS which is costing Malay support for the party. This is even recorded in the Prime Minister's observation "I heard then even PAS feels uncomfortable when he turns up during by-elections. There are even some who send massages to request that he does not attend" (PM: support for.., 2011). However, temporarily it was a great save from embarrassment for PAS that in Merlimau at least it decided not to field its top vice president Tuan Ibrahim.

And finally, BN is delighted to see the opposition alliance bogged down and its political stream lost its current. The opposition alliance has been experiencing ever increasing internal disunity that the components have been suffering from mistrust, noncooperation, contradiction, disagreement and in some cases liability for each other. Its grand ambition of working on common policy framework has been working very loosely. As such, the grand opposition weakness is taken as political win by the $\mathrm{BN}$ even before the next general elections.

\section{Conclusions}

By-elections are common in parliamentary democracy and they are not insignificant. At times they can make great impact on national political system as was witnessed elsewhere like in Bangladesh in the mid 1990s where the alleged corruption in Magura by-election turned the institution of Election Commission irrelevant, elections under party-government unreliable, and introduced a new transitional Caretaker Government to conduct the national elections (Molla, 2000; Riaz, 2005). In Malaysia, by-elections after the 2008 general elections were considered very important because these could make great impacts on both the ruling and opposition alliances. Wining in by-elections was a political urgency and prerogative for the ruling $\mathrm{BN}$ to get the party on track after serious blow it suffered in the 2008 elections. Wining for $\mathrm{BN}$ even became more urgent in the face of eight losses out of 11 by-elections till November 2009; similarly, winning was equally significant for the opposition bloc to continue its momentum of eight wins during the same time. However, the scenario changed drastically after November 2009 in favour of BN through its straight winning track record in all the subsequent by-elections. Merlimau being the last bore special significance for the $\mathrm{BN}$ to get its recently introduced economic programs tested. A greater majority for $\mathrm{BN}$ in this by-election compared with 2008 election has undoubtedly boosted the political morale of the party to do still better in the next general election in the country. The fact that the ruling party's image has been serious questioned by many over the recent $1 \mathrm{MD}$ scandal such competitive by-elections like Merlimau can make a deep transforming impact on the political landscape of the nation.

\section{Acknowledgement}

This research is financed by the Research Management Center of the International Islamic University Malaysia. 


\section{References}

Abu, B. Z. (2011, March 7). Why the Malays are returning to Umno. New Straits Time, p. 7.

BN to field popular candidate in Merlimau. (2011, January 22). MY Sinchew, accessed February 14, 2011, http://www.mysinchew.com/node/51887.

Case, W. (2011). Electoral Authoritarianism and Backlash: Hardening Malaysia and Oscillating Thailand. International Political Science Review, 32(4), 438-57. http://dx.doi.org/10.1177/0192512110385296

Case, W. (2014). Malaysia in 2013: A Benighted Election Day (and Other Events). Asian Survey, 54(1), 56-63. http://dx.doi.org/10.1525/as.2014.54.1.56

DAP blames lottery fiasco: ban might have caused loss of favour with Chinese voters. (2011, March 8). The Star, N6.

Elis, S. (2011, March 6). Malays will determine winner. New Sunday Times, p. 6.

Gasper, Desiree Tresa. (2011, March 8). Chua: PAS sidelines DAP: Lottery ban indicates party no consulted over policies. The Star, N12.

Hamzah, M. H., Nur Qurratul' A. I., Kamarudin, N., Jamaludin, M., Mohd, F. A. R., \& Zaherawati, Z. (2014). Permatang Pauh by Elections: Analysis Approach Framing Content in the Prime Media Selected. Asian Social Science, 10(4), 46-51. http://dx.doi.org/10.5539/ass.v10n4p46

Heng: Don't politicise efforts to help the poor. (2011, March 2). The Star, N4.

Heng, S. B. (2011, March 6). Chinese voters enjoy peace and stability. New Sunday Times, p. 6.

Huat, W. C., \& Soon, L. T. (2012). Democracy at Stake? Examining 16 by-elections in Malaysia 2008-2011, Kuala Lumpur: Strategic Information and Research Development Centre.

Ishak, M. S. A., \& Fong, Y. (2013). Covering Galas and Batu Sapi By-Elections: Framing By Chinese Newspapers. International Journal of Asia Pacific Studies, 9(2), 15-47.

Johansson, A. C. (2014). On the Challenge to Competitive Authoritarianism and Political Patronage in Malaysia. Retrieved March 10, 2016, from http://swopec.hhs.se/hascer/papers/hascer2014-029.pdf

John, J. G. (2011 March 6). Barisan has the edge on this turf. New Sunday Times, p. 5.

Khalid, K. Md., \& Halimah, A. (2008). Voting Patterns: Evidence from the 2004 Malaysian General Elections. Journal of Politics and Law, 1(4), 33-44. http://dx.doi.org/10.5539/jpl.v1n4p33

Malacca aims to finish project: Zakat fund will be used for complex. (2011, March 2). The Star, N6.

Melaka BN Ready For Merlimau By-election. (2011, January 29). Bernama. Retrieved February 13, 2011, from http://www.bernama.com/bernama/v5/newsindex.php?id=560466 Melaka PAS says 'ready' for Merlimau by-election. (2011, February 9). Harakah Daily, Retrieved February 10, 2011, from http://en.harkahdaily.net.index.php?option=com_content\&view=article\&id=2242:melaka 
Molla, G. (2000). Democratic Institution Building Process in Bangladesh: South Asian Experience of a New Model of a 'Care-taker Government' in a Parliamentary Framework. Working Paper No. 3, December, University of Heidelberg: Heidelberg Papers in South Asian and Comparative Politics, pp. 1-16.

Moniruzzaman, M. (2013). The 13th Malaysian General Election: Uncertainties and Expectations. Intellectual Discourse, 21(1), 55-70.

Nakamura, M. (2013). Elections of State Legislative Assembly in Peninsular Malaysia. In K. B. Teik (Ed.). 13th General Elections in Malaysia: Issues, Outcomes and Implications, Tokyo: IDE-JETRO.

Moten, A. R. (2009). 2004 and 2008 General Elections in Malaysia: Towards a Multicultural, Bi-party Political System? Asian Journal of Political Science, 17(2), 173-194. http://dx.doi.org/10.1080/02185370903077469

Moten, A. R. (2009). 2008 General Elections in Malaysia: Democracy at Work. Japanese Journal of Political Science, 10(01), 21-42. http://dx.doi.org/10.1017/S1468109908003356

Najib vows to do his best for Merlimau and Kerdau. (2011, March 7). The Star, N2.

Opposition to meet on candidate for Merlimau. (2011, January 30). My Sinchew. Retrieved February 25, 2011, from http://www.mysinchew.com/node/52431

Pandian, S. (2009). 2004 Malaysian General Elections Winning Formula. Journal of Law and Politics, 2(4), 93-97. http://dx.doi.org/10.5539/jpl.v2n4p93

PAS Youth wants PAS to contest in Merlimau. (2011, January 25). MY Sinchew, Retrieved February 25, 2011, from http://www.mysinchew.com/node/52062

Pepinsky, T. B. (2007). Autocracy, Elections, and Fiscal Policy: Evidence from Malaysia. Studies in Comparative International Development, 42, 136-163. http://dx.doi.org/10.1007/s12116-007-9006-4

PM: Support for BN growing: By-election wins show people believe coalition can solve their problems. (2011, March 8). The Star, N4.

Prasad, K. (2015). Identity Politics and Elections in Malaysia and Indonesia: Ethnic Engineering in Borneo, Singapore: Routledge.

Puthucheary, M., \& Norani, O. (eds.) (2005). Elections and Democracy in Malaysia. Selangor: UKM.

Riaz, A. (2005). Bangladesh in 2004: The Politics of Vengeance and the Erosion of Democracy. Asian Survey, 45(1), 112-118. http://dx.doi.org/10.1525/as.2005.45.1.112

Saravanamutu, J., Lee, H. G. \& Mohamed, N. M. O. (eds). (2015). Coalitions in Collision: Malaysia's 13th General Elections, Singapore: ISAS (Chapter 1).

Tan, J. (2011a, March 3). An open market in Merlimau. The Star, N25.

Tan, J. (2011b, March 5). Campaign hitting below the belt. The Star, N33.

Tan, J. (2011c, March 4). Opposition a hard sell in Merlimau. The Star, N28.

Tan, J. (2011d, March 7). Barisan back in the driver's seat. The Star, N27.

Tuker improves lives: Small retailer transformation programme shows results. (2011, March 4). The Star, N18. 


\section{Macrothink}

Journal of Social Science Studies

ISSN 2329-9150

2016, Vol. 3, No. 2

Weiss, M. L. (2013). Malaysia's 13th General Elections: Same Result, Different Outcome. Asian Survey, 53(6), 1135-1158. http://dx.doi.org/10.1525/as.2013.53.6.1135

Welsh, B. (2013). Malaysia's Elections: A Step Backward. Journal of Democracy, 24(4), 136-150. http://dx.doi.org/10.1353/jod.2013.0066

Yee, F. P. (2011a, March 5). By-election appetiser draws 'em in. The Star, N32.

Yee, F. P. (2011b, March 4). Still New Year here in Merlimau. The Star, N34.

Yee, F. P. (2011c, March 2). Red Rocket hardly visible. The Star, N28.

Yee, F. P. (2011, March 1). DPM: Hot leaflets not our style: BN denies any part in distributing 'sexy' posters of Pakatan leaders. The Star, N8.

\section{Copyright Disclaimer}

Copyright for this article is retained by the author(s), with first publication rights granted to the journal.

This is an open-access article distributed under the terms and conditions of the Creative Commons Attribution license (http://creativecommons.org/licenses/by/3.0/). 